\title{
Differential Suppression of Rice Weeds by Allelopathic Plant AqueOUS EXTRACTS ${ }^{1}$
}

\author{
Supressão Diferencial de Plantas Daninhas do Arroz pelos Extratos Aquosos de Plantas \\ Alelopáticas
}

\author{
KHALIQ, A. ${ }^{2 *}$, MATLOOB, A. ${ }^{2}$, KHAN, M.B. ${ }^{3}$, and TANVEER, A. ${ }^{2}$
}

\begin{abstract}
Herbicidal potential of different plant aqueous extracts was evaluated against early seedling growth of rice weeds in pot studies. Plant aqueous extracts of sorghum (Sorghum bicolor), sunflower (Helianthus annuus), brassica (Brassica compestris), mulberry (Morris alba), eucalyptus (Eucalyptus camaldunensis), and winter cherry (Withania somnifera) at a spray volume of $18 \mathrm{~L} \mathrm{ha}^{-1}$ each at the 2-4 leaf stage of rice weeds viz horse purslane (Trianthema portulacastrum) [broad-leaf], jungle rice (Echinochloa colona), and E. crus-galli (barnyard grass) [grasses] and purple nut sedge (Cyperus rotundus) and rice flat sedge (C. iria) [sedges]. The results showed significant interactive effects between plant aqueous extracts and the tested weed species for seedling growth attributes depicting that allelopathic inhibition was speciesspecific. Shoot and root length, lateral plant spread, biomass accumulation, and leaf chlorophyll contents in test species were all reduced by different extracts. The study suggested the suppressive potential of allelopathic plant aqueous extracts against rice weeds, and offered promise for their usefulness as a tool for weed management under field conditions.
\end{abstract}

Keywords: allelopathy, aqueous extracts, seedling growth, weeds, inhibition.

RESUMO - O potencial herbicida dos extratos aquosos de diferentes plantas foi avaliado por meio do crescimento inicial de plântulas de plantas daninhas do arroz em bioensaios. Extratos aquosos de folhas de sorgo (Sorghum bicolor), girassol (Helianthus annuus), brássicas (Brassica compestris), amoreira (Morris alba), eucalipto (Eucalyptus camaldulensis) e cereja-de-inverno (Withania somnifera) foram aplicados num volume de calda de $18 \mathrm{~L} \mathrm{ha-1}$, na fase de 2-4 folhas, sobre as seguintes espécies de plantas daninhas do arroz: beldroega-cavalo (Trianthema portulacastrum) [folhas largas]; arroz-selva (Echinochloa colona) e capim (E. cruss-galli) [gramineas]; e tiririca-roxa (Cyperus rotundus) e tiririca-arroz-plana (C. iria) [ciperáceas]. Os resultados mostraram efeitos significativos na interação entre os extratos aquosos das plantas testadas $e$ as diferentes espécies de plantas daninhas no que diz respeito ao crescimento das plântulas, o que demonstra que a inibição alelopática foi específica. O efeito dos diferentes extratos nas espécies estudadas manifestou-se na redução do comprimento das raizes, na propagação lateral/vegetativa das plantas, na acumulação de biomassa foliar e no teor de clorofila. O estudo sugere o potencial inibitório dos extratos aquosos de plantas alelopáticas no controle de plantas daninhas do arroz e salienta a possibilidade de seu uso como ferramenta para manejo dessas plantas em campo.

Palavras-chave: alelopatia, extratos aquosos, crescimento das plântulas, inibição de plantas daninhas.

1 Recebido para publicação em 21.6.2011 e aprovado em 14.7.2012.

2 Department of Agronomy, University of Agriculture, Faisalabad, Pakistan; ${ }^{3}$ University College of Agriculture, Bahauddin Zakariya University, Multan, Pakistan, <khaliquaf@gmail.com>, <khaliquaf@gmail.com>. 


\section{INTRODUCTION}

Weeds are one of the worst biological constraints to direct seeded rice cultures (Rao et al., 2007). Associated with the direct seeding of rice is an inevitable shift in weed flora to more difficult-to-control and non-native weeds in rice fields. An appropriate weed control strategy comprised chiefly of herbicides has always been a major input and key element to sustain profitable rice production. However, the development of resistance in some previously susceptible weed species, as well as serious environmental concerns owing to high residual effects of herbicides in soil are major drawbacks associated with continuous herbicide usage (Ahn et al., 2005). Resistance of rice weeds to a number of herbicides has also been reported (Rao et al., 2007), probably because these target only a few molecular sites (Duke, 1990). In fact, the 270 herbicides covering the global market represent only 17 modes of action with almost half of them acting as ALS (acetolactate synthase), PS II (photosystem II), and Protox inhibitors (Macias et al., 2007).

Given the increasing emphasis placed on sustainable agriculture, and concern about the adverse effects of extensive use of farm chemicals, research attention is now being focused on reducing the dependence upon synthetic herbicides, and finding alternative strategies for weed management. Focused work on plant derived materials as an environmentally friendly alternative approach for weed control in field crops has been under way for the last two decades (Kuk et al., 2001). Utilization of the allelopathic properties of native plant/crop species offers promising opportunities for this purpose. Many crop/ plant species have been screened during the recent past for their allelopathic activity with an emphasis placed on weed management in agricultural systems. Allelopathic plants such as sorghum (Sorghum bicolor) (Cheema \& Khaliq, 2000; Weston \& Duke, 2003), sunflower Helianthus annuus) (Anjum \& Bajwa, 2010), brassica (Brassica compestris) (Uremis et al., 2009), eucalyptus (Eucalyptus camaldulensis) (Dadkhah \& Asaadi, 2010), mulberry (Morus alba) (Hong et al., 2004; Jabran et al., 2010), and winter cherry (Withania somnifera) (Jabran et al., 2010; Knox et al., 2010) are inhibitory to certain weeds.
Allelopathic potential of plant species can be exploited in many ways, and the utilization of the aqueous extracts of these species is one possible tool. Different plant species contain allelochemicals that vary in type and concentration (Xuan et al., 2005). Weeds can be better controlled by the utilization of plants that possess a greater fraction of allelochemicals (Elijarrat \& Barcelo, 2001). Identification of plant species with greater allelopathic potential, and the characterization of their adverse effects against weeds is required for better ecological based weed management. These plants can also prove to be a potential source of allelochemicals as a lead for natural herbicides (Vyvyan, 2002). Little information is available regarding the phytotoxic effect, if any, of the plant extracts of sorghum, sunflower (brassica, eucalyptus, mulberry, and winter cherry against rice weeds. The suppressive allelopathic potential of these extracts was evaluated in pot studies on early seedling growth of rice weeds viz. horse purslane (Trianthema portulacastrum) [broad-leaf], jungle rice (Echinochloa colona) and E. crus-galli (barnyard grass) [grasses] and purple nut sedge (Cyperus rotundus) and rice flat sedge $(C$. iria) [sedges]. The agro-ecological significance of the results obtained for weed management in rice fields is also discussed.

\section{MATERIALS AND METHODS}

\section{Preparation of extracts}

Mature above ground foliage of sorghum, sunflower, brassica, winter cherry, leaves of mulberry, and eucalyptus plants were collected. These were stored and dried under shade to avoid possible leaching by rain water. To prepare the aqueous extracts, each plant material was chopped with an electric fodder cutter into $2-3 \mathrm{~cm}$ pieces. The chopped plant material was soaked in distilled water for $24 \mathrm{~h}$ at room temperature $\left(25 \pm 5{ }^{\circ} \mathrm{C}\right)$ in a ratio of $1: 10(\mathrm{w} / \mathrm{v})$ and was filtered through a 10 and 60 mesh sieve. Initial volume of the distilled water for soaking was $10 \mathrm{~L}$ that, after filtration, remained $7 \mathrm{~L}$. The respective extracts were boiled at $100{ }^{\circ} \mathrm{C}$ to concentrate up to 20 times for easy handling and application. Previous studies revealed that boiling did not affect the nature, relative composition, or efficacy of allelochemicals (Jamil et al., 2009). 
To exclude the notion of inhibitory effect due to the $\mathrm{pH}$ and osmotic potential of the plant aqueous extracts and skip possible concerns about the ecological implications of allelopathy, these two attributes were also measured for each of the aqueous extract. The $\mathrm{pH}$ and electrical conductivity of the extracts were recorded with digital $\mathrm{pH}$ and conductivity meters (HI-9811, Hannah, USA). The osmotic potential of different extract concentrations was computed as:

Osmotic potential $(-\mathrm{Mpa})=\mathrm{Ec}\left(\mathrm{ds} \mathrm{m}^{-1}\right) \mathrm{x}-0.036$

\section{Bioassay}

Foliar application of allelopathic plant aqueous extracts was evaluated for their suppressive effects on the seedling growth of rice weeds. Plastic pots $(29 \times 18 \mathrm{~cm}$, $10 \mathrm{~kg}$ capacity) were filled with air dried, sieved, well mixed soil ( $\mathrm{pH}$ of saturated soil paste and electrical conductivity (EC) of the saturation extract were 7.9 and $0.41 \mathrm{~d} \mathrm{Sm}^{-1}$, respectively). After germination, five seedlings (2-4 leaf stage, BBCH scale growth stage 12-14) of each weed species were maintained in each pot and placed in a screen house with natural solar radiation and an average temperature of $35 \pm 5{ }^{\circ} \mathrm{C}$. Allelopathic plant aqueous extracts of sorghum, sunflower, brassica, mulberry, eucalyptus, and winter cherry each at $18 \mathrm{~L} \mathrm{ha}^{-1}$ (60 $\mathrm{mL} \mathrm{L}^{-1}$ of water) were sprayed on the $10^{\text {th }}$ day after sowing with the help of a hand operated atomizer. Volume of the spray solution (300 $\mathrm{L} \mathrm{ha}^{-1}$ ) was determined by using water. Control pots were sprayed with distilled water. These pots were irrigated as and when required to keep the soil moist and avoid water stress.

Both the root and shoot lengths were measured on the $14^{\text {th }}$ day after foliar application of plant aqueous extracts. All roots and shoots from each pot were cut separately and oven dried at $70{ }^{\circ} \mathrm{C}$ for $48 \mathrm{~h}$ to obtain the dry biomass of root and shoot; total seedling biomass was calculated as the sum of biomass of root and shoot. Number of leaves, tillers, and/or lateral shoots/sprouts were counted manually and averaged. Chlorophyll content was measured after extraction in $80 \%$ ice cold acetone as per Lichtenthaler \& Wellburn (1987), read by a UV-spectrophotometer (UV-4000, ORI,
Germany), and are expressed as $\mathrm{mg} \mathrm{g}^{-1}$ fresh leaf weight.

\section{Experimental design and statistical analysis}

Pots were placed in a factorial arrangement using a completely randomized design with four replications. Following an analysis of variance technique (Steel et al., 1997), the mean values were separated using the least significant difference (LSD) at $\mathrm{P} \leq 0.05$ employing MSTAT-C (Freed \& Scott, 1986). Standard errors were calculated using MS-Excel.

\section{RESULTS AND DISCUSSION}

The results suggested the phyto-toxicity of allelopathic plant aqueous extracts against the seedling growth of weeds. A suppressive influence on the shoot and root lengths of weed seedlings varying in magnitude was enforced by almost all plant aqueous extracts used in this experiment (Table 1). Significant $(P \leq 0.05)$ interactive effects for weed species and extracts were observed on all the seedling growth attributes depicting that allelopathic inhibition was species specific. Eucalyptus inhibited the shoot and root lengths of horse purslane to a maximum of 36 and $20 \%$, whereas mulberry and winter cherry promoted its root length by $24 \%$ over the control. Brassica and sorghum recorded a maximum (44 and 32\%) reduction in shoot and root length of jungle rice, respectively. Mulberry aqueous extract recorded a maximum suppression in the shoot length of barnyard grass, while sorghum was most toxic to its root length. A perusal of the data (Table 1) also indicated that eucalyptus aqueous extract recorded the highest suppression in shoot length (60\%) while brassica accounted for maximum inhibition in root length (56\%) of purple nut sedge. Shoot length of flat sedge appeared more susceptible to sorghum (53\%) while its root length was more inhibited by eucalyptus (64\%) aqueous extract.

The seedling shoot and root lengths have been the most frequently used parameters for the expression of allelopathic potential (Inderjit \& Dakhshini, 1995; Prately et al., 1999). The inhibition of shoot and root growth in the tested weed species upon exposure to allelopathic 
Table 1 - Influence of allelopathic plant aqueous extracts on the shoot and root lengths of rice weeds

\begin{tabular}{|c|c|c|c|c|c|}
\hline Allelopathic plant & T. portulacastrum & E. colona & E. crus-galli & C. rotundus & C. iria \\
\hline \multicolumn{6}{|c|}{ Shoot length $(\mathrm{cm})$} \\
\hline Control & $28.53 \mathrm{~cd}^{* *} \pm 1.99$ & $36.07 \mathrm{~b} \pm 1.93$ & $46.73 \mathrm{a} \pm 3.01$ & $36.93 \mathrm{~b} \pm 1.30$ & $28.00 \mathrm{c}-\mathrm{e} \pm 1.83$ \\
\hline Sorghum AE* & $19.80 \mathrm{f}-\mathrm{m} \pm 2.27$ & $23.47 \mathrm{~d}-\mathrm{h} \pm 1.74$ & $30.20 \mathrm{c} \pm 1.68$ & $20.93 \mathrm{f}-\mathrm{k} \pm 0.84$ & $13.13 \mathrm{n} \pm 0.50$ \\
\hline Sunflower AE & $19.67 \mathrm{~g}-\mathrm{m} \pm 3.37$ & $28.47 \mathrm{~cd} \pm 0.25$ & $27.50 \mathrm{c}-\mathrm{e} \pm 1.53$ & $18.33 \mathrm{~h}-\mathrm{n} \pm 2.08$ & $16.73 \mathrm{j}-\mathrm{n} \pm 1.07$ \\
\hline Brassica AE & $20.67 \mathrm{f}-1 \pm 1.12$ & $20.13 \mathrm{f}-1 \pm 0.64$ & $27.00 \mathrm{c}-\mathrm{e} \pm 2.18$ & $20.00 \mathrm{f}-1 \pm 1.31$ & $15.471-\mathrm{n} \pm 0.12$ \\
\hline Mulberry AE & $21.53 \mathrm{f}-\mathrm{j} \pm 1.86$ & $22.87 \mathrm{e}-\mathrm{i} \pm 1.15$ & $24.40 \mathrm{~d}-\mathrm{g} \pm 2.21$ & $21.13 \mathrm{f}-\mathrm{k} \pm 1.29$ & $17.73 \mathrm{i}-\mathrm{n} \pm 1.07$ \\
\hline Eucalyptus AE & $18.20 \mathrm{i}-\mathrm{n} \pm 1.39$ & $24.27 \mathrm{~d}-\mathrm{g} \pm 1.64$ & $24.73 \mathrm{~d}-\mathrm{g} \pm 1.83$ & $14.67 \mathrm{mn} \pm 0.75$ & $16.93 \mathrm{j}-\mathrm{n} \pm 1.20$ \\
\hline Winter cherry AE & $24.60 \mathrm{~d}-\mathrm{g} \pm 1.74$ & $24.90 \mathrm{~d}-\mathrm{f} \pm 1.17$ & $27.67 \mathrm{c}-\mathrm{e} \pm 1.17$ & $16.30 \mathrm{k}-\mathrm{n} \pm 0.80$ & $21.53 \mathrm{f}-\mathrm{j} \pm 0.46$ \\
\hline LSD P $\leq 0.05$ & \multicolumn{5}{|c|}{ Interaction $=5.229$} \\
\hline \multicolumn{6}{|c|}{ Root length $(\mathrm{cm})$} \\
\hline Control & $10.00 \mathrm{c}-\mathrm{g} \pm 1.50$ & $14.33 \mathrm{~b} \pm 0.76$ & $17.80 \mathrm{a} \pm 1.42$ & $11.00 \mathrm{c}-\mathrm{f} \pm 0.50$ & $5.77 \mathrm{k}-\mathrm{n} \pm 0.34$ \\
\hline Sorghum AE & $9.33 \mathrm{e}-\mathrm{I} \pm 1.26$ & $9.67 \mathrm{~d}-\mathrm{h} \pm 0.76$ & $10.13 \mathrm{c}-\mathrm{g} \pm 1.81$ & $8.67 \mathrm{f}-\mathrm{j} \pm 0.76$ & 3.33 no \pm 0.76 \\
\hline Sunflower AE & $9.33 \mathrm{e}-\mathrm{i} \pm 1.53$ & $11.00 \mathrm{c}-\mathrm{f} \pm 0.66$ & $11.33 \mathrm{c}-\mathrm{e} \pm 1.28$ & $7.33 \mathrm{~h}-\mathrm{k} \pm 1.04$ & 3.83 no \pm 0.14 \\
\hline Brassica AE & $10.00 \mathrm{c}-\mathrm{g} \pm 0.87$ & $12.33 b c \pm 0.58$ & $12.00 \mathrm{~b}-\mathrm{d} \pm 1.53$ & $4.851-n \pm 0.07$ & 3.50 no \pm 0.90 \\
\hline Mulberry AE & $12.33 \mathrm{bc} \pm 0.29$ & $12.00 \mathrm{~b}-\mathrm{d} \pm 0.50$ & $11.40 \mathrm{c}-\mathrm{e} \pm 1.02$ & $7.00 \mathrm{i}-1 \pm 1.32$ & $4.601-n \pm 0.26$ \\
\hline Eucalyptus AE & $8.00 \mathrm{~g}-\mathrm{k} \pm 1.50$ & $12.17 \mathrm{bc} \pm 0.72$ & $11.03 \mathrm{c}-\mathrm{f} \pm 1.61$ & $6.83 \mathrm{j}-\mathrm{m} \pm 0.88$ & $2.10 \mathrm{o} \pm 0.09$ \\
\hline Winter cherry AE & $12.40 \mathrm{bc} \pm 0.72$ & $12.17 b c \pm 1.42$ & $12.27 b c \pm 1.45$ & $5.67 \mathrm{k}-\mathrm{n} \pm 1.04$ & $4.50 \mathrm{~m}-\mathrm{o} \pm 0.75$ \\
\hline LSD $\mathrm{P} \leq 0.05$ & \multicolumn{5}{|c|}{ Interaction $=2.441$} \\
\hline
\end{tabular}

*Aqueous extract; ** Means with different letters differ significantly at the $5 \%$ level of probability by an LSD test.

plant aqueous extracts may be attributed to phytochemicals present in these extracts. The $\mathrm{pH}$ and osmotic potential of different extracts ranged between 6.20 to 6.80 and -0.50 bars to 0.88 bars, respectively, and both were unlikely to avert plant growth, and growth inhibition was thought presumably due to inhibitory compounds present in the aqueous extracts. Netzly \& Butler (1986) and Cheema et al. (2009) reported several phytotoxins such as gallic acid, protocatechuic acid, syringic acid, vanillic acid, p-hydroxybenzoic acid, p-coumaric acid, benzoic acid, ferulic acid, $\mathrm{m}$ coumaric acid, caffeic acid, p-hydroxybenzaldehyde and sorgoleone in sorghum. Sunflower also contains allelochemicals viz. chlorogenic acid, isochlorogenic acid, á naphthol, scopolin, and annuionones (Macias et al., 2002; Anjum \& Bajwa, 2005). The members of the Brassicaceae family contain glucosinolates that, upon hydrolysis, yield isothiocyanates (Jiménez-Osornio \& Gliessman, 1987), and isoprenoids and benzoids (Tollsten \& Bergstrom, 1988) that exert allelopathic effects on the germination and growth of other species (Uremis et al., 2009). Eucalyptus species are considered to be one of the most notorious allelopathic trees and release sufficient quantities of terpenes, phenylpropanoids, quinones, coumarins, flavonoids, tannins, phenolic acids, glycosides, and cyanogens (Einhellig, 1986). Allelochemicals of mulberry and winter cherry have remained undiscovered until now although their allelopathic potential has also been reported in some recent studies by Jabran et al. (2010). Reduced root and shoot lengths of test weed species can be due to alterations in DNA synthesis in their respective apical meristems, mitochondrial metabolism (Abrahim et al., 2000) or changes in cell mitotic indices (Iganci et al., 2006) or a combination of all of them. Al-Wakeel et al. (2007) reported that retarded seedling elongation might be an outcome of the direct interference of allelochemicals with the process of cell division that alters the balance of different growth hormones. Differences in the activity of different extracts in suppressing the seedling growth of the tested weed species may be due to difference/s in the type and concentration of allelochemicals present in these extracts (Xuan et al., 2005).

A reduction in leaf score and lateral branches/tillers/side shoots (Table 2) of tested weed species indicated that the size of 
Table 2 - Influence of allelopathic plant aqueous extracts on leaf score and lateral branches/tillers/side shoots of rice weeds

\begin{tabular}{|c|c|c|c|c|c|}
\hline Allelopathic plant & T. portulacastrum & E. colona & E. crus-galli & C. rotundus & C. iria \\
\hline \multicolumn{6}{|c|}{ Leaf score } \\
\hline Control & $76.33 \mathrm{a}^{* *} \pm 8.69$ & $21.87 \mathrm{~d} \pm 0.93$ & $15.73 \mathrm{~d}-\mathrm{g} \pm 1.33$ & $8.53 \mathrm{e}-\mathrm{j} \pm 0.60$ & 9.13 e-j \pm 0.32 \\
\hline Sorghum AE* & $47.67 \mathrm{c} \pm 4.82$ & $16.73 \mathrm{~d}-\mathrm{f} \pm 1.10$ & $7.53 \mathrm{~g}-\mathrm{j} \pm 0.31$ & $6.73 \mathrm{~g}-\mathrm{j} \pm 0.21$ & $4.60 \mathrm{j} \pm 0.35$ \\
\hline Sunflower AE & $57.00 \mathrm{~b} \pm 7.78$ & $15.67 \mathrm{~d}-\mathrm{h} \pm 0.64$ & $7.73 \mathrm{f}-\mathrm{j} \pm 1.46$ & $4.67 \mathrm{j} \pm 0.49$ & $5.40 \mathrm{j} \pm 0.56$ \\
\hline Brassica AE & $49.33 \mathrm{c} \pm 1.32$ & $3.1821 .47 \mathrm{~d} \pm 1.69$ & $7.00 \mathrm{~g}-\mathrm{j} \pm 0.90$ & $6.67 \mathrm{~h}-\mathrm{j} \pm 0.67$ & $4.67 \mathrm{j} \pm 0.49$ \\
\hline Mulberry AE & $58.00 \mathrm{bc} \pm 3.12$ & $11.20 \mathrm{e}-\mathrm{j} \pm 1.23$ & $6.73 \mathrm{~g}-\mathrm{j} \pm 0.32$ & $7.40 \mathrm{~g}-\mathrm{j} \pm 0.30$ & $5.00 \mathrm{j} \pm 0.44$ \\
\hline Eucalyptus AE & $37.67 b c \pm 4.54$ & $17.53 \mathrm{de} \pm 1.88$ & $8.47 \mathrm{f}-\mathrm{j} \pm 0.95$ & $6.00 \mathrm{j} \pm 0.61$ & $4.93 \mathrm{j} \pm 0.59$ \\
\hline Winter cherry AE & $78.33 \mathrm{a} \pm 7.40$ & $15.47 \mathrm{~d}-\mathrm{i} \pm 1.69$ & $5.33 \mathrm{j} \pm 0.40$ & $6.53 \mathrm{ij} \pm 0.40$ & $6.60 \mathrm{ij} \pm 0.70$ \\
\hline \multirow{2}{*}{\multicolumn{6}{|c|}{$\begin{array}{l}\text { Interaction }=9.029 \\
\text { Lateral branches/tillers/side shoots }\end{array}$}} \\
\hline & & & & & \\
\hline Control & $30.00 \mathrm{a} \pm 3.97$ & 7.40 ef \pm 0.36 & $4.67 \mathrm{e}-\mathrm{j} \pm 0.51$ & $8.00 \mathrm{e} \pm 0.50$ & $4.80 \mathrm{e}-\mathrm{j} \pm 0.56$ \\
\hline Sorghum AE* & $20.00 b c \pm 1.32$ & $5.20 \mathrm{e}-\mathrm{i} \pm 0.40$ & $1.87 \mathrm{ij} \pm 0.21$ & $4.33 \mathrm{f}-\mathrm{j} \pm 0.76$ & $1.67 \mathrm{j} \pm 0.31$ \\
\hline Sunflower AE & $24.33 \mathrm{ab} \pm 2.08$ & $4.33 \mathrm{f}-\mathrm{j} \pm 0.25$ & $1.73 \mathrm{ij} \pm 0.40$ & $2.67 \mathrm{~h}-\mathrm{j} \pm 0.58$ & $2.40 \mathrm{~h}-\mathrm{j} \pm 0.26$ \\
\hline Brassica AE & $18.00 \mathrm{bc} \pm 0.50$ & $6.40 \mathrm{e}-\mathrm{g} \pm 0.53$ & $2.00 \mathrm{ij} \pm 0.40$ & $3.33 \mathrm{~g}-\mathrm{j} \pm 0.29$ & $2.60 \mathrm{~h}-\mathrm{j} \pm 0.36$ \\
\hline Mulberry AE & $24.67 \mathrm{ab} \pm 2.02$ & $4.00 \mathrm{f}-\mathrm{j} \pm 0.44$ & $1.73 \mathrm{ij} \pm 0.31$ & $5.67 \mathrm{e}-\mathrm{h} \pm 0.76$ & $2.67 \mathrm{~h}-\mathrm{j} \pm 0.32$ \\
\hline Eucalyptus AE & $16.00 \mathrm{c} \pm 2.18$ & $5.07 \mathrm{e}-\mathrm{j} \pm 0.32$ & $2.33 \mathrm{~h}-\mathrm{j} \pm 0.21$ & $4.33 \mathrm{f}-\mathrm{j} \pm 0.29$ & $2.93 \mathrm{~g}-\mathrm{j} \pm 0.51$ \\
\hline Winter cherry AE & $29.67 \mathrm{a} \pm 1.89$ & $4.67 e-j \pm 0.49$ & $1.73 \mathrm{ij} \pm 0.21$ & $3.67 g-j \pm 0.76$ & $2.93 \mathrm{~g}-\mathrm{j} \pm 0.42$ \\
\hline LSD P $\leq 0.05$ & \multicolumn{5}{|c|}{ Interaction $=3.489$} \\
\hline
\end{tabular}

* Aqueous extract; ** Means with different letters differ significantly at the $5 \%$ level of probability by an LSD test.

photosynthesizing machinery was also drastically suppressed. Eucalyptus and mulberry accounted for the greatest suppression of these characteristics in horse purslane (51 and $47 \%$ ), and jungle rice (49 and $46 \%$ ). Winter cherry was the most suppressive against leaf score $(66 \%)$ and mulberry against tillering $(63 \%)$ in barnyard grass. Sunflower and sorghum appeared more inhibitory to purple nut sedge (45 and $67 \%$ ) and flat sedge (50 and $65 \%$ ), respectively. Likewise, there was a reduction of fresh and dry biomass of weed seedlings relative to control under the influence of all the aqueous extracts (Figure $1 \mathrm{~A}$ and 1B). However, again a species specific response regarding both extract sources and tested weed species was indicated by the presence of a significant interaction $(\mathrm{P} \leq 0.05)$ between these. Eucalyptus aqueous extract was more effective in retarding the dry matter accumulation of horse purslane $(49 \%)$ and jungle rice $(59 \%)$ seedlings while winter cherry scored maximum $(>60 \%)$ fresh and dry weight suppression of barnyard grass. Sunflower was the most detrimental to purple nut sedge and sorghum and brassica aqueous extracts to flat sedge. The total chlorophyll content of weed leaves treated with allelopathic plant aqueous extracts declined compared to the control (Figure 1C) and variable levels of reductions were observed for different weeds species under the influence of different extracts.

Disturbance and alteration in seedling morphology under allelopathic stress in our studies can be explained by alteration in mitochondrial respiration thus yielding less ATP for energy consuming processes (Gniazdowska \& Bogatek, 2005). Allelochemicals in plant aqueous extracts might have inhibited chlorophyll in the tested weed species by interfering with the biosynthesis of photosynthetic pigments or enhancing their degradation or through the integration of both (Huang et al., 2010). Changes in chlorophyll contents in our studies are also supported by the findings of Inderjit \& Dakshini (1992) who cited allelochemical-mediated reduction in seedling photosynthetic pigments primarily due to phenolic acids.

Although the exploitation of allelopathy as a natural weed management tool is eyecatching as an eco-friendly weed management approach yet contrary to bioassays, the suppression achieved under field conditions is often negligible (Duke et al., 2001). Many 
KHALIQ, A. et al.
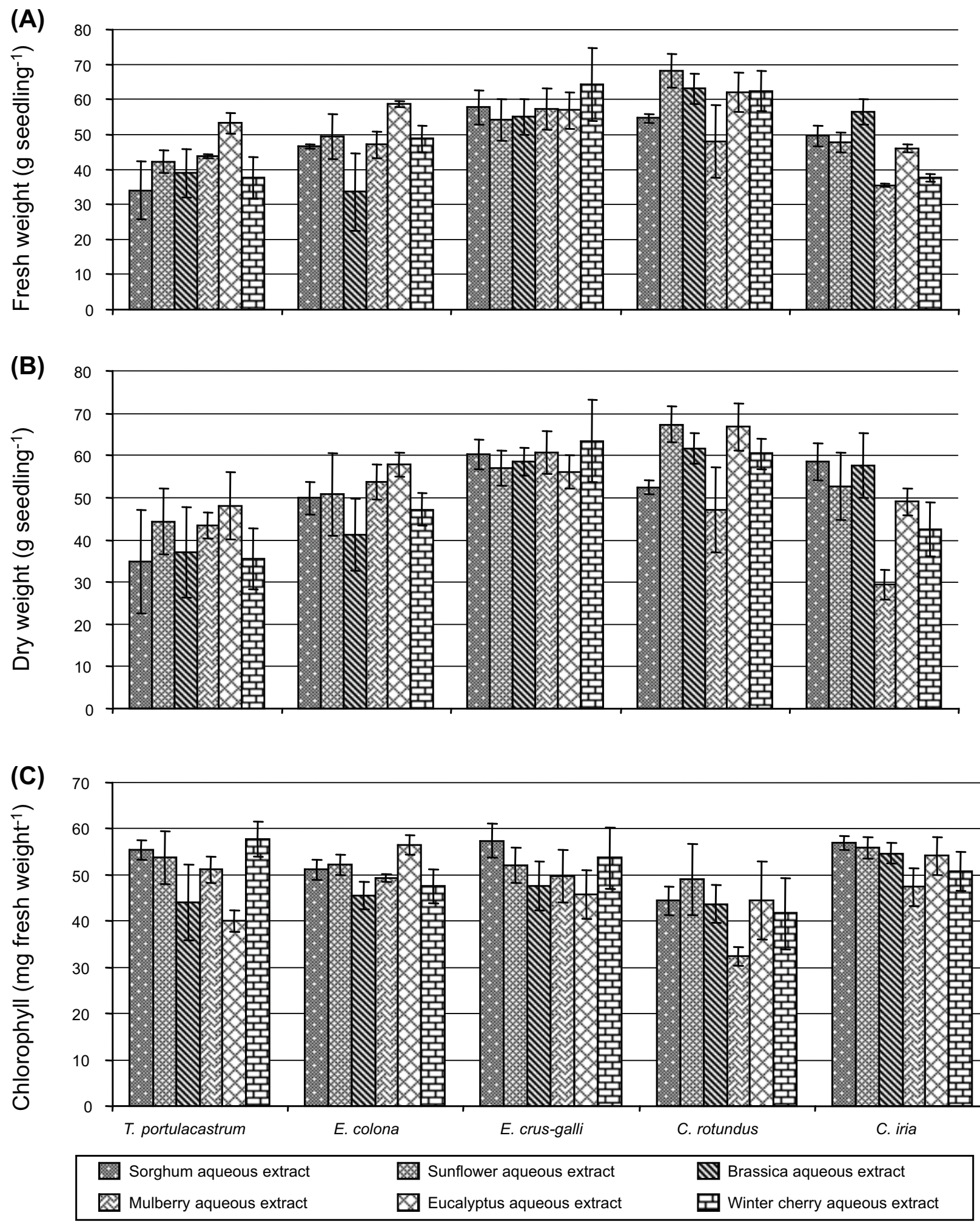

Figure 1 - Influence of allelopathic plant aqueous extracts on seedling fresh (A) and dry (B) weight (g) and (C) chlorophyll contents of rice weeds ( $\mathrm{mg} \mathrm{g}^{-1}$ fresh weight), expressed as percentage inhibition over control. Vertical bars above mean denote the standard error of four replicates. 
studies have obtained contrasting results under controlled and natural conditions (Inderjit \& Weston, 2000). Nonetheless, soil possesses the ability to detoxify allelochemicals, so the bioassays conducted under controlled conditions in the absence of soil might be misleading due to an overestimation of the allelopathic potential (Foy, 1999; Inderjit, 2001). It is imperative to conclude whether these allelochemicals can accumulate under field conditions and affect individuals of a weed community. This confirms the need to carry out field trials to quantify suppression caused by an allelopathic species. It is often impossible to simulate the exact field conditions in laboratory trials, but an effort was made in the present studies by using soil as a growing medium with the objectives of maintaining the physical, chemical, and biological soil factors of the natural setting. Inderjit (2001) also discussed the significance of soils in the expression of allelopathy that may be explained under field or pot experiments. Foy (1999) concluded that in terrestrial systems any bioassay without involving soil has no ecological relevance. Moreover, the pots were placed under screen house and under open environments. Despite their known limitations and criticism received, bioassays are useful tools as early proof for allelopathic potential. Our data showed strong inhibitory potential of different species against the seedling growth of tested weed species. Seedling biomass can be used as a bio-indicator for the inhibitory effect of allelopathic extracts. Although the reduction in seedling biomass is specific for both donor and receiver species, but the aqueous extracts of sunflower and eucalyptus were more suppressive to a number of weeds, and may be evaluated by applying either at a higher concentration or in combination in order to cope with the diversity of weed flora in rice fields. Efforts are needed to identify and isolate the most effective allelochemicals from these species in a quest for natural herbicide molecules.

\section{ACKNOWLEDGEMENTS}

The financial support from the Higher Education Commission, Government of Pakistan under the National Research Program is gratefully acknowledged.

\section{LITERATURE CITED}

ABRAHIM, D. et al. Effects of four monoterpenes on germination, primary root growth, and mitochondrial respiration of maize. J. Chem. Ecol., v. 26, n. 3, p. 611-624, 2000 .

$\mathrm{AHN}, \mathrm{J}$. K. et al. Evaluation of allelopathic potential among rice (Oryza sativa L.) germination for control of Echinochloa crus-galli P. Beauv in the field. Crop Protec., v. 24, n. 5, p. 413-419, 2005.

AL-WAKEEL, S. A. M. et. al. Allelopathic effects of Acacia nilotica leaf residue on Pisum sativum L. Allelopathy J., v. 19, n. 2, p. 411-422, 2007

ANJUM, T.; BAJWA, R. A bioactive annuionone from sunflower leaves. Phytochemistry, v. 66, n. 16, p. 1919$1921,2005$.

ANJUM, T.; BAJWA, R. Isolation of bioactive allelochemicals from sunflower (Variet Suncross-42) through fractionation-guided bioassays. Nat. Prod. Res., v. 24, n. 18, p. $1783-1788,2010$

CHEEMA, Z. A.; KHALIQ, A. Use of sorghum allelopathic properties to control weeds in irrigated wheat in a semi arid region of Punjab. Agric. Ecosyst. Environ., v. 79, n. 2-3, p. $105-112,2000$.

CHEEMA, Z. A. et al. Purple nutsedge management with allelopathic sorghum. Allelopathy J., v. 23, n. 2, p. 305-312, 2009.

DADKHAH, A.; ASAADI, A. M. Allelopathic effects of Eucalyptus camaldulensis on seed germination and growth seedlings of Acroptilon repens, Plantago lanceolata and Portulaca oleracea. Res. J. Biol. Sci., v. 5, n. 6, p. 430-434, 2010.

DUKE S. O. Overview of herbicide mechanisms of action. Environ. Health Persp., v. 87, n. 1, p. 263-271, 1990.

DUKE, S. O. et. al. Allelochemicals as herbicides. In: BONJOCH, N. P.; REIGOSA, M. J. (Eds.). EUROPEAN OECD ALLELOPATHY SYMPOSIUM: PHYSIOLOGICAL ASPECTS OF ALLELOPATHY. Vigo: Gamesal, 2001. p. $47-59$.

EINHELLIG, F. A. Mechanism and mode of action of allelochemicals. In: PUTNAM, A. R.; TANG, C. S. (Eds.). The science of allelopathy. New York: John Wiley and Sons, 1986. p. 171-188.

ELIJARRAT, E.; BARCELO, D. Sample handling and analysis of allelochemical compounds in plants. Trends Anal. Chem., v. 20, n. 10, p. 584-590, 2001.

Planta Daninha, Viçosa-MG, v. 31, n. 1, p. 21-28, 2013 
FOY, C. L. How to make bioassays for allelopathy more relevant to field conditions with particular reference to cropland weeds. In: INDERJT et al. (Eds.). Principles and practices in plant ecology: allelochemicals interactions. Boca Raton: CRC Press, 1999. p. 25-33.

FREED, R. D.; SCOTT, D. E. MSTATC. Crop and soil. Michigan: Michigan State University, 1986.

GNIAZDOWSKA, A; BOGATEK, R. Allelopathic interactions between plants: Multi site action of allelochemicals. Acta Physiol. Plant., v. 27, n. 3, p. 395-407, 2005.

HONG, N. H. et al. Paddy weed control by higher plants from Southeast Asia. Crop Protec., v. 23, n. 3 p. 255-261, 2004.

HUANG, J. H. et al. Allelopathic effects of cassava (Manihot esculenta crantz.) on radish and rye grass (Lolium perene L.). Allelopathy J., v. 25, n. 1, p. 155-162, 2010.

IGANCI, J. R. V. et. al. Efeito do extrato aquoso de diferentes espécies de boldo sobre a germinação e índice mitótico de Allium cepa L. Arq. Inst. Biol., v. 73, n. 1, p. 79-82, 2006

INDERJTT. Soils: environmental effect on allelochemical activity. Agron. J., v. 93, n. 1, p. 79-84, 2001.

INDERJIT; DAKSHINI, K. M. M. On laboratory biossays in allelopathy. Bot. Rev., v. 61, n. 1, p. 28-44, 1995.

INDERJIT; DAKSHINI, K.M.M. Interference potential of Pluchea lanceolata (Asteraceae): growth and physiological responses of asparagus bean, Vigna unguiculata var. sesquipedalis. Am. J. Bot., v. 79, n. 9, p. 977-981, 1992.

INDERJIT; WESTON, L. A. Are laboratory bioassays for allelopathy suitable for prediction of field responses? J. Chem. Ecol., v. 26, n. 9, p. 2111-2118, 2000.

JABRAN, K. et al. Wild oat (Avena fatua) and canary grass (Phalaris minor Ritz.) management through allelopathy. J. Plant Protect. Res., v. 50, n. 1, p. 41-44., 2010.

JAMIL, M. Alternative control of wild oat and canary grass in wheat fields by allelopathic plant aqueous extracts. Agron. Sustain. Develop., v. 29, n. 3, p. 475-482, 2009.

JIMÉNEZ-OSORNIO, J. J.; GLIESSMAN, S. R. Allelopathic interference in a wild mustard (Brassica campestris L.) and broccoli (Brassica oleracea L. var. italica) intercrop agroecosystems. In: WALLER, G. R. (Ed.). Allelochemicals: role in agriculture and forestry. Washington, D.C: ACS, 1987. p. 262-274.
KNOX, J. et al. Evaluation of allelopathic plant species on Parthenium hysterophorus. Egyptian J. Biol., v. 12, n. 1, p. 57-64, 2010.

KUK, Y. I. et al. Evaluation of rice by-products for weed control. Weed Sci., v. 49, n. 1, p. 141-149, 2001.

LICHTENTHALER, H. K.; WELLBURN, A. Chlorophyll and carotenoids: pigments of photosynthetic bio-membranes. In: PACKER, L.; DOUCE, R. (Eds.). Methods in enzymology. San Diego: Academic Press, 1987. p. 350-382.

MACAIS, F. A. et al. Allelopathy- a natural alternative for weed control. Pest Manag. Sci., v. 63, n. 4, p. 327-348, 2007.

MACIAS F. A. et al. Bioactive terpinoids from sunflower leaves cv. Peredovick. Phytochemistry, v. 61, n. 6, p. 687-692, 2002.

NETZLY, D. H.; BUTLER, L. G. Roots of sorghum exude hydrophobic droplets containing biologically active components. Crop Sci., v. 26, n. 4, p. 775-780, 1986.

PRATLEY, J. E. et al. Following a specific protocol establish allelopathy conclusively-an Australian case study. In: MACIAS, F. A. et al. (Eds.). Recent advances in Allelopathy: a science for future. Cádiz: Servicio de Publicaciones, Universidad de Cádiz, 1999. p. 63-70.

RAO, A. N. et al. Weed management in direct seeded rice. Adv. Agron., v. 93, n. 1, p. 153-255, 2007.

STEEL, R. G. D. et al. Principles and procedures of statistics: a biometrical approach. 3.ed. New York: McGraw Hill Book, 1997. p. 172-177.

TOLLSTEN, L.; BERGSTROM, G. Headscape volatiles of whole plant and macerated plant parts of brassica and sinapis Phytochemistry, v. 27, n. 12, p. 4013-4018, 1988.

UREMIS, I. et al. Allelopathic potential of residue of 6 brassica species on johson grass [Sorghum halepense (L.) Pers.]. Afr. J. Biotechem., v. 8, n. 15, p. 3497-1501, 2009

VYVYAN, J. R. Allelochemicals as leads for new herbicides and agrochemicals. Tetrahedron, v. 58, n. 9, p. 1631-1646, 2002.

WESTON, L. A.; DUKE, S. O. Weed and crop allelopathy. Crit. Rev. Plant Sci., v. 22, n. 3/4, p. 367-389, 2003.

XUAN, T. D. et al. Biological control of weeds and plant pathogens in paddy fields by exploiting plant allelopathy: an overview. Crop Protec., v. 24, n. 1, p. 197-206, 2005. 